\title{
Conservation Program Participation and Adaptive Rangeland Decision-Making
}

\author{
M. N. Lubell, ${ }^{1}$ B. B. Cutts, ${ }^{2}$ L. M. Roche, ${ }^{3}$ M. Hamilton, ${ }^{4}$ J. D. Derner, ${ }^{5}$ E. Kachergis, ${ }^{5}$ \\ and K. W. Tate
}

Authors are ${ }^{1}$ Professor, Department of Environmental Science and Policy, University of California, Davis, CA, 95616, USA; ${ }^{2}$ Assistant Professor, Department of Natural Resources and Environmental Sciences, University of Illinois at Urbana-Champaign, Champaign, IL 61820, USA; ${ }^{3}$ Postdoctoral Scholar, Department of Plant Sciences, University of California, Davis, CA, 95616, USA; ${ }^{4}$ Doctoral Student, Department of Environmental Science and Policy, University of California, Davis, CA, 95616, USA; ${ }^{5}$ Supervisory Research Rangeland Management Specialist and Research Leader and ${ }^{6}$ PostDoctoral Scholar, USDA-ARS Rangeland Resources Research Unit, Cheyenne, WY 82009, USA; and ${ }^{7}$ Rangeland Watershed Specialist, Department of Plant Sciences, University of California, Davis, CA, 95616, USA.

\begin{abstract}
This paper analyzes rancher participation in conservation programs in the context of a social-ecological framework for adaptive rangeland decision-making. We argue that conservation programs are best understood as one of many strategies of adaptively managing rangelands in ways that sustain livelihoods and ecosystem services. The framework hypothesizes four categories of variables affecting conservation program participation: operation/operator characteristics, time horizon, social network connections, and social values. Based on a mail survey of California ranchers, multinomial logit models are used to estimate the impact of these variables on different levels of rancher involvement in conservation programs. The findings suggest that ranchers with larger amounts of land, an orientation towards the future, and who are opinion leaders with access to conservation information, are more likely to participate in conservation programs.
\end{abstract}

Key Words: ecosystem services, management, social networks

\section{INTRODUCTION}

This paper analyzes California ranchers' participation in conservation programs in the context of a social-ecological framework for adaptive rangeland decision-making. We focus primarily on the four most popular programs in California: Environmental Quality Incentives Program (EQIP), Conservation Reserve Program (CRP), California's Williamson Act, and conservation easements. EQIP and CRP are both US Department of Agriculture programs that provide incentives for conservation management; EQIP provides technical assistance for implementation of environmental practices, while CRP provides rental payments for removing environmentally sensitive land from production. California's Williamson Act is a unique state program that allows ranchers to enter into contracts with local governments to preserve open space in return for lower property tax assessments. Conservation easements are a voluntary agreement between a landowner and a wide variety of governmental and nongovernmental organizations, where the landowner agrees to limit development on conservation land, and receives income and estate tax benefits.

Conservation programs are playing larger roles than they have in the recent past as strategies for helping ranchers adapt to the dynamics of complex rangeland systems (Merenlender et al. 2004; Brunson and Huntsinger 2008; Briske 2011; Claassen

Research was funded by the USDA-NIFA, Rangeland Research Program, Grant 200938415-20265.

Correspondence: M. N. Lubell. Department of Environmental Science and Policy, University of California, Davis, CA, 95616, USA. Email: mnlubell@ucdavis.edu

Manuscript received 4 February 2013; manuscript accepted 26 August 2013.

(c) 2013 The Society for Range Management
2011; Pavelis et al. 2011). This reflects a growing awareness of the idea of ecosystem services among a diverse set of rangeland management stakeholders, including range scientists, environmental groups, ranchers, and agency officials (Merenlender et al. 2004; Havstad et al. 2007; Huntsinger et al. 2010). For example, the total acres of land in the Western United States being enrolled in conservation easements has outpaced land development from 1997 to today (Christensen et al. 2011). In California, partnerships like the California Rangeland Conservation Coalition have worked to forge collaboration among diverse rangeland stakeholders. One partner in the Coalition, the rancher-founded California Rangeland Trust, from 2000 to 2011 has enrolled in conservation easements over 250000 acres on over 40 separate properties (California Rangeland Trust 2011).

\section{Adaptive Decision-Making in Rangelands}

Conservation programs are best understood using an adaptive decision-making framework (Fig. 1), which emphasizes how the sustainability of individual ranching operations depends on their capacity to adapt to the changing parameters of the socialecological systems in which their enterprises are embedded (Folke et al. 2005; Gross et al. 2006; McAllister et al. 2006; Gillson and Hoffman 2007; Fox. et al. 2009; Brunson 2012). The social components of the system include economic and market forces, public policies, community values, and local social networks that connect ranchers to other actors. The ecological system includes spatial and temporal variability in parameters that affect rangeland productivity and health, such as forage and water availability. The dynamics of these socialecological parameters vary over space and time, operate at multiple spatial scales (local, regional, national, and global), and feature high levels of uncertainty (Quaas et al. 2007). 


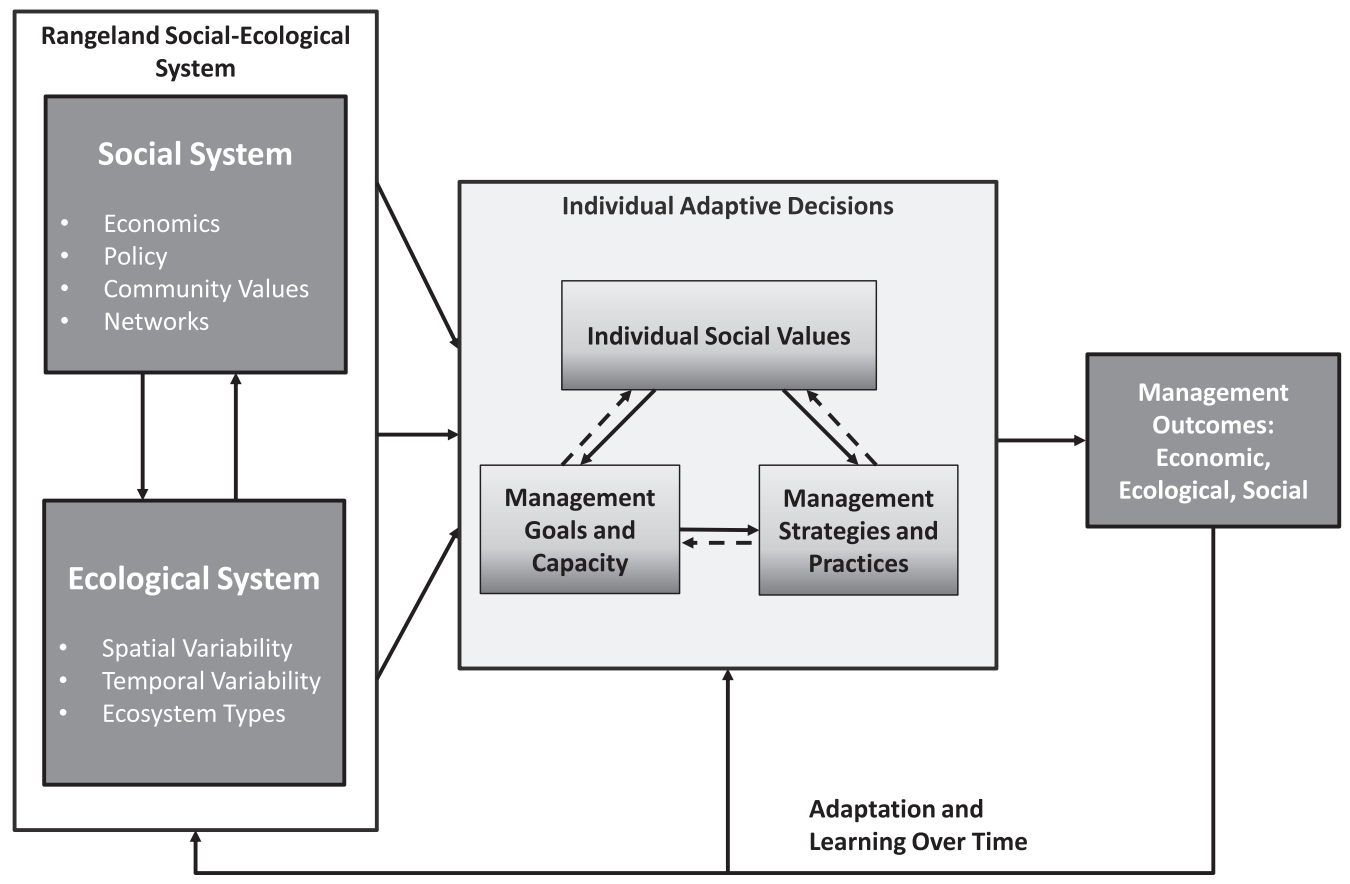

Figure 1. Adaptive decision-making for rangeland management.

Individual management decisions are shaped by social values and management capacity, and management outcomes feedback at both the individual and system scales. While this paper focuses on rangelands, the adaptive decision-making framework is generally applicable to any agro-ecological system.

Conservation programs are part of the portfolio of management strategies that ranchers mix and match to achieve their goals and manage risk in the face of uncertainty and complexity (Stafford Smith and McAllister 2008; McAllister et al. 2009). Conservation program participation entails moving from a situation of lack of awareness to making concrete choices among known options. This is consistent with an overall decision-making process that involves trial-and-error learning along with the development of heuristics (Payne et al. 1990; Gigerenzer and Selten 2002) and place-based expertise (Lai and Kreuter 2012) that function to guide decisions. Management strategies may incorporate new technologies, but are often passed down in families and learned from others in a rancher's knowledge network (Lubell et al. 2011), which includes policy stakeholders as well as other ranchers.

The framework integrates and extends existing theories of agricultural decision-making, especially diffusion of innovations (Fuglie and Kascak 2001; Rogers 2003; Kreuter et al. 2006; Lubell and Fulton 2008) and the theory of planned behavior (Ajzen and Fishbein 1980; Ahnström et al. 2009; Knapp and Fernandez-Gimenez 2009; Sorice et al. 2011). Diffusion theory treats ranchers as rational actors, who rely on social networks to acquire information about the costs and benefits of various management strategies and practices. The theory of planned behavior analyzes the link between management goals and practices, including the amount of control a rancher has over decisions and how social values affect goal formation.

The framework argues that economics, psychology, and social networks operate simultaneously as components of the broader social-ecological system. In addition, it addresses the importance of time horizons in affecting how ranchers think about adapting their management strategies. While the framework is more complex than some other theories, there are benefits to a richer conceptual approach that identifies an integrative set of variables and reflects the diversity of strategies used by ranchers over space and time.

\section{Key Variables Affecting Rancher Participation in Rangeland Conservation Programs}

Table 1 summarizes the variables expected to influence levels of participation in conservation programs. These hypotheses are synthesized from the existing literature on agricultural decision-making and rangeland management, in particular research that draws on diffusion theory and the theory of planned behavior. The adaptive decision-making framework integrates and extends these approaches.

Operation and Operator Characteristics. Almost every theory and empirical analysis of agricultural decision-making considers operation and operator characteristics to be important (Prokopy et al. 2008). Buttel and Newby (1980; see also Napier et al. 2000) call this the "farm structure" approach. In line with this research, we argue that the operator/operation characteristics shape the costs and benefits of different management strategies and practices, and thus relate to the central economic goals of ranchers and their capacity to integrate ecosystem services and conservation programs into their overall management portfolio.

A standing hypothesis is that larger ranches, in terms of number of privately owned or leased acres and acres leased on public land, are more likely to have an economically viable operation and large enough budget constraints to try innovative strategies (Thurow et al. 2000; Kreuter et al. 2004). Across California and other Western United States, many ranchers 
Table 1. Variables hypothesized to influence conservation program participation.

\begin{tabular}{l}
\hline Operator and operation characteristics \\
•Privately owned/leased acres (Acres) \\
• Publicly leased acres (Acres) \\
•Education (1-7 scale) \\
-Income (1-7 scale) \\
•Number of off-ranch income sources ( $0-6$ count) \\
Time horizon \\
• Succession plan (yes/no) \\
•Number of generations ranching (1-5 scale) \\
Social network connections \\
• Opinion leadership (1-5 scale) \\
•Number of conservation information sources (1-4 scale) \\
Social values \\
•Views on property rights (1-5 scale) \\
•Views on government role in protecting private property (1-5 scale) \\
•Trust in government involvement in conservation (1-5 scale) \\
\hline
\end{tabular}

have diverse operations that include a private home ranch, other privately owned parcels, and parcels leased for grazing on private and public lands (Bureau of Land Management and US Forest Service). Larger operations typically support more animals as well. The same budget argument applies to ranchers with higher incomes (Peterson and Coppock 2001), which is partly a function of operation size but can also include offranch income sources.

While the number of sources of off-ranch income relates to the affordability of conservation programs, it also reflects other important aspects of rancher strategies. Ranchers who rely on a wider range of income sources may view ranching as less of a central lifestyle choice, and may be more open to integrating a broader set of goals (Ferranto et al. 2011; Sorice et al. 2012). Off-ranch income diversifies the economic portfolio of an operation, providing a more flexible budget constraint that makes it easier to participate in conservation programs that may reduce direct income from grazing. A diverse set of offranch income sources also suggests a willingness to innovate, a personality trait expected to apply to conservation programs.

Finally, education as measured through traditional schooling (i.e., high school through advanced degree) may increase participation rates for a number of reasons. Better-educated ranchers may have been exposed to a broader range of information about conservation programs, and be more comfortable negotiating the often-complex bureaucratic processes involved with enrollment (Coppock and Birkenfeld 1999). Education is one of the main predictors of environmental values among general citizens (Kollmuss and Agyeman 2002), and thus more-educated ranchers are expected to place a greater emphasis on conservation and ecosystem services goals. Of course, as will be discussed later, traditional education is not the only way ranchers learn about practices and programs.

Time Horizon. Adaptive decision-making requires long-term planning to anticipate possible changes in the social-ecological parameters surrounding a particular operation. Longer timehorizons are also linked to what economists call a lower "discount rate," which increases the net present value of future expected benefits. Ranchers who are seriously considering the long-term sustainability of their operation will often develop a written succession plan detailing how the operation will be handed over to future generations. The presence of a succession plan is thus an indicator of a lower discount rate (Mishra and El-Osta 2007) and is therefore expected to be associated with more participation in conservation programs. In fact, succession plans may include specific details about maintaining portions of the property in conservation easements or other programs.

Another indicator of a long-term outlook and low discount rate is the number of family generations a ranch has been in operation. Ranchers often take great pride in sustaining a longterm presence in a rural community, and many ranches in the Western United States date back to the homesteading era of the 19th century. Multigenerational ranches have successfully adapted to the dynamics of the social-ecological system over a long period of time and also have developed a strong sense of place linked to the history of their families and communities. Multigenerational ranching families often express a desire to continue their tradition into the future, and advocate protecting working landscapes and providing economic opportunities for younger generations in rural areas. These attributes are linked to a lower discount rate and longer time horizon, and thus also expected to increase participation in conservation programs (Didier and Brunson 2004).

Social Networks. Social networks are key factors in diffusion theory, due to their role in spreading information about the costs and benefits of different management practices. Lubell and Fulton (2008) describe a broader role for social networks in the context of agriculture, including building local social capital for solving cooperation problems, and facilitating the evolution of cultural norms such as an ethic for conservation. Many observers argue that a conservation ethic is an increasingly important part of the ranching culture, as evidenced by increasing rates of participation in conservation programs and the emergence of boundary-spanning organizations like the California Rangeland Conservation Coalition (Sulak and Huntsinger 2002), which aim to build cooperation among ranching and conservation interests.

Local organizations that provide information about conservation programs are one important source of social network connections. These include conservation-focused nongovernmental organizations, local offices of the Natural Resources Conservation Service, Resource Conservation Districts, Cooperative Extension, and university researcher programs that partner with ranchers and commodity groups. These organizations usually have a local presence that allows the development of personal and trust-based relationships. Such relationships are key conduits for information about conservation practices and programs, and help ranchers negotiate the bureaucratic procedures associated with participation (Huntsinger and Hopkinson 1996; Rissman and Sayre 2012).

Individual ranchers vary in terms of how much they communicate with others in their community, and how wellrecognized they are as opinion leaders. These two traits combined are associated with overall centrality in a social network (Valente and Pumpaung 2007; Iyengar et al. 2011; Molitor et al. 2011). In the language of social network analysis, 


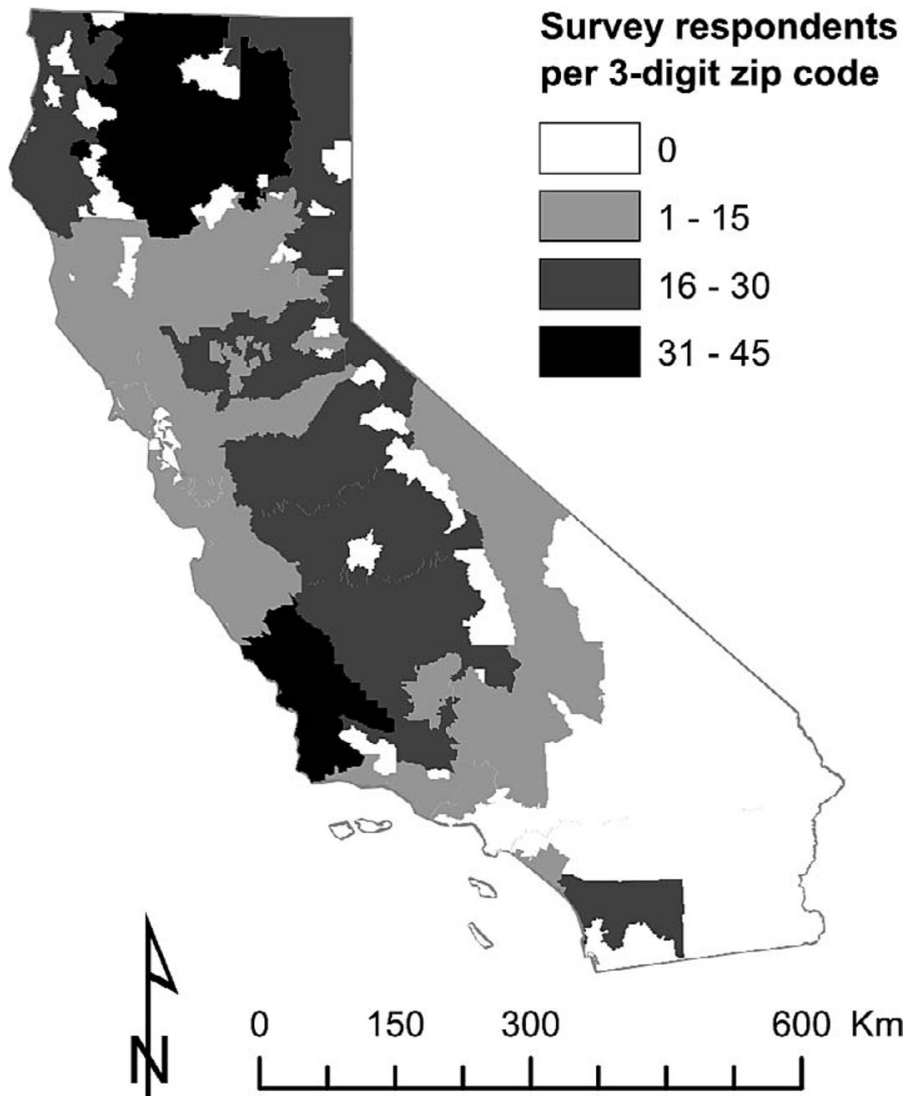

Figure 2. Geographic distribution in California rangeland survey respondents.

people who reach out to many others have a high "out-degree" centrality-many social network connections directed to other people. People who are recognized by others as opinion leaders have high "in-degree" centrality - they are considered knowledgeable actors, and so many people seek to form ties with them. Taken together, ranchers who are central in social networks are expected to access more information about conservation programs and provide opinion leadership in innovative management strategies and practices.

Social Values. Psychological theories, such as the theory of planned behavior and other theories that focus on the belief systems of individuals (Peffley and Hurwitz 1985), argue that social values shape goals and beliefs and affect the cognitive processes by which people process information about their environment. Attitudes towards property rights are considered some of the most relevant social values for ranchers (JacksonSmith et al. 2005). These include views on what people are allowed to do with their private property, and the role of government in protecting private property rights vs. eroding them with additional policy requirements. The conventional hypothesis is that a strong adherence to private property rights values will decrease participation in conservation programs, because they are perceived to be a constraint on individual freedoms (Merenlender et al. 2004; Kabii and Horwitz 2006).

However, there is much anecdotal and some empirical evidence that the dialog regarding conservation programs and private property rights has changed in the recent past (Kreuter et al. 2006). There is no philosophical reason that conservation programs are antithetical to property rights-it is within the private rights of each landowner to make the voluntary decision to enroll or not in a conservation program. Just because the programs are often sponsored by the government does not necessarily infringe on private property rights.

Given the importance of the government and conservation groups in this context, a key issue is how much ranchers trust government to be helpful in promoting conservation goals (Lubell 2007). Some ranchers may think the government is extremely unhelpful, creating too many bureaucratic barriers to participation and trying to force ranchers to change their practices. Other ranchers may view the government as helpful, for example when a local agency employee assists in negotiating the bureaucratic process, or the government provides cost-share money. Thus we expect positive views of government to have an overall stronger influence on program participation than property rights views, which are potentially experiencing a change in dialog.

\section{METHODS}

\section{California Rangeland Survey Design and Analysis}

To test hypotheses regarding conservation management programs, we developed a mail survey of California ranchers using the membership list of the California Cattlemen's Association (CCA) as the sampling frame. Regular membership is defined on the CCA membership page as available to "cattle producers or owners of property on which cattle are run" (http://www. calcattlemen.org/members/membershipapplication.html). While not all ranches in California are CCA members, we believe the sampling frame captures the large majority of production ranches. However, our results do suggest smaller operations are underrepresented in the CCA membership.

The final survey was delivered to 1727 addresses. Question design was informed by previous research, interviews with 12 ranchers, and pretesting at agricultural meetings. Following Dillman's Tailored Design Method (Dillman 2007), we used a multipronged approach to develop awareness and enhance the legitimacy of the survey. This included print and online advertisements endorsed by the CCA and the California Farm Bureau Federation. Ranchers received four waves of contact from March to June 2011: a survey and a return envelope, a reminder letter that included the option to refuse the survey or note ineligibility, a second survey packet, and a final reminder postcard.

We received 511 useable surveys (waves of 193, 118, 62, 116 following each mailing and 22 late or volunteered responses) and confirmed 93 ineligible addresses. The response rate is $33 \%$ (American Association of Public Opinion Research, Response Rate 4 includes an estimate of the number of ineligible nonrespondents in the denominator). Figure 2 shows that our survey respondents are well-distributed throughout the geography of California's rangelands. However, there is evidence that CCA membership does not include many small and hobby operations. Among survey respondents, $3 \%$ had 0 to 19 cattle and calves; $30 \%$ had 20 to $99 ; 52 \%$ had 100 to $499 ; 13 \%$ had 500 to 2499 and $2 \%$ had 2500 or more. In contrast, the 2007 Census of Agriculture (National Agricultural Statistical Service 2007) reports 52\%, 23\%, 12\%, 9\%, and 3\% 


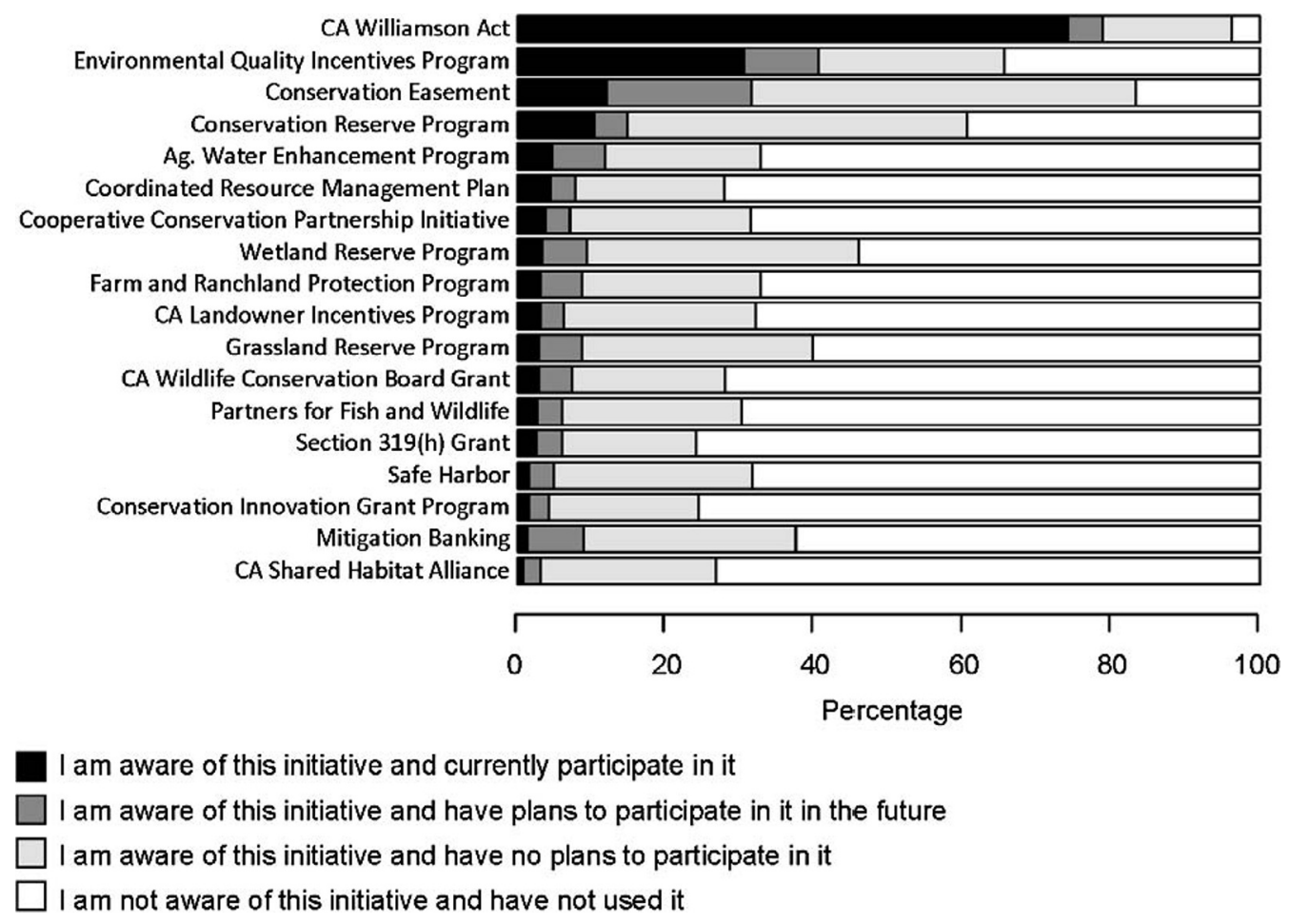

Figure 3. Participation choices in conservation programs in California.

for the same categories, respectively. Hence, we cannot generalize our results to smaller ranchers, although the results report some interesting effects of ranch size even within the observed size range.

To test for survey nonresponse bias, we conducted nonparametric tests of response across the four successive waves of the survey. We found evidence of nonresponse bias with a slightly declining level of overall program participation across successive waves (Kruskall-Wallis $=7.037 ; P=0.071$ ), but no differences for other variables that suggested a response trend. But the declining trend for program participation is quite gradual, and does not seriously compromise the interpretation of the results.

\section{Dependent Variables: Rates of Participation in Conservation Management Programs}

For 18 different conservation programs, we asked ranchers to select whether they were not aware of the program, aware but choose not to participate, aware and currently participate, or aware with plans to participate in the future. Following the adaptive decision-making framework's emphasis on decision making over time, this question format allows respondents to indicate a range of different behavioral responses rather than just a yes/no question. Figure 3 shows the basic results from these questions.

The low level of awareness for the majority of these programs is particularly notable; only the top four programs (Williamson Act, EQIP, conservation easements, and CRP) have awareness over $50 \%$. Except for Williamson Act and EQIP, most ranchers who are aware of a particular program do not intend to participate in it.

In the statistical analysis below, we use the answers to these questions as categorical response variables or choice variables in multinomial logit models. For short, we label the choices "unaware," "no plans," "currently," and "future." For the top four programs, we estimate multinomial logit models that predict the probabilities of making each choice. We also construct a variable that sums up the total number of programs in which a rancher currently participates. This overall participation scale is a count variable that ranges from 0 to 10 with an average of 1.5 programs, and measures the level of participation across the entire menu of conservation programs.

\section{Independent Variable Measurement}

The survey was used to construct measures of the each of the independent variables listed in Table 1. Private acres indicates the overall scale of the operation, and is the sum of total privately owned acres plus acres leased from other private landowners. Public acres is the number of acres leased from public lands agencies like the Bureau of Land Management and the US Forest Service. Education is a 1 to 7 scale that ranges from "did not graduate high school" to "advanced degree." Income is a categorical 1 to 7 scale that ranges from less than $\$ 49000$ per yr to more than $\$ 300000$ per yr, and asks the rancher to consider both on-ranch and off-ranch sources. Number of off-ranch income sources counts up the number of "yes" answers to seven types of possible sources: other agricultural production, nonextractive recreation, conventional energy-development, extractive recreation, alternative energy development, and any other unspecified activity.

Succession plan is a dichotomous $(0 / 1)$ dummy variable that indicates whether a rancher has completed or is currently preparing a succession plan that identifies a strategy for keeping land in ranching in the future. Generations is a count variable with five different levels: $1=$ First generation rancher; $2=\mathrm{My}$ parents were ranchers; $3=\mathrm{My}$ grandparents were ranchers; 
$4=$ My great grandparents were ranchers; and 5=My great, great grandparents were ranchers.

The social network variables were measured in two ways. First, we used two attitude questions shown to be associated with different measures of network centrality (Valente and Pumpaung 2007; Iyengar et al. 2011; Molitor et al. 2011). The following five-point disagree-agree Likert scale measured "outdegree" and information sharing: "I share information with groups of ranchers who would not otherwise communicate with each other." A similar scale measured opinion leadership: "I think most ranchers in California consider me to be an opinion leader in the industry." These questions were highly correlated, and were averaged into a single reliable scale we labeled opinion leader (Cronbach's alpha $=0.65$ ). While the Cronbach's alpha score is slightly less than the traditional 0.70 rule-of-thumb, alpha can be interpreted as a lower bound for estimating reliability and is biased downwards when there are few items included in the scale (Cortina 1993).

A second indicator of social network connections is the conservation information sources scale, which summarizes each respondent's level of contact with five organizations that provide information about conservation programs: Conservation/environmental groups, Natural Resources Conservation Service, Resource Conservation District, University of California Cooperative Extension, and college/university researchers. The combined scale (Cronbach's alpha $=0.69$ ) averages the following response categories across the five different organizations: $1=$ Never use; $2=$ Poor quality information; $3=$ Good quality information source; and $4=$ Excellent quality information. While this scale combines information about information use and quality, it has a correlation of 0.93 with a scale that merely sums the number of information sources that are used ignoring the quality evaluation (i.e., each information sources is coded as use or not use). The qualitative results of the multinomial logit models are also not changed when using a simpler count scale.

Lastly, three Likert-scale questions $(1=$ Fully Disagree through 5=Fully Agree) were used to measure basic social values related to private property rights and the role of government in conservation:

- Role of Government: Upholding the private property rights of individual citizens is the most important role of government.

- Private Property Rights: My landowner rights allow me the absolute right to do whatever I want without regard for what others prefer.

- Government Trust: Government involvement in conservation has helped ranchers.

\section{Statistical Models}

Our main analytical strategy is to use multinomial logit models to estimate the probability of choosing different levels of participation (Long 1997; Greene 2000). The parameters (see Tables S1-S4 for full model results; available online at http:// dx.doi.org/10.2111/REM-D-13-00025.s1) in a multinomial logit model can be thought of as a series of logistic regressions where the probability of each choice is compared to a baseline, which in this case is the "unaware" category. Positive coefficients increase the probability of choosing a particular option (i.e., "no plans," "currently," and "future") relative to the baseline, while negative parameters reduce the probability.

We conducted a series of preliminary analyses to zero in on the key independent variables that influence choices for each of the top four programs. First, we estimated models that included only the operator/operation variables and retained those variables significant at the 0.10 level. We then estimated models with all of the other independent variables except conservation information sources. The models shown in the supplemental tables (available online at http://dx.doi.org/10. 2111/REM-D-13-00025.s1) include the significant variables that remained after this initial screening. We then added conservation information sources as an independent variable in a final series of models. We took this approach because conservation information is correlated with many of the other independent variables, creating multicollinearity that tends to mask the effects of the other variables. In addition, including conservation information as an independent variable makes the strong assumption that choosing to participate in a program does not have a reciprocal influence on the development of information networks. We return to this issue later in the analysis discussion.

Multinomial logit models are easiest to interpret in terms of the factor change in the odds ratio of choosing one option versus another, as a function of a specified change in the independent variables (Long 1997). These factor changes are calculated from a mathematical transformation of the raw multinomial logit coefficients. For example, our results show that a one standard deviation change in the opinion leader scale leads to a 1.79 increase in the odds ratio of currently participating in a conservation easement vs. being not aware. This can be interpreted as a $79 \%$ increase in the odds of currently participating in an easement; the formula to compute the percentage is (factor ratio-1)*100.

\section{RESULTS}

\section{Predicting Participation in Popular Programs}

Because multinomial logit models entail many different contrasts, it is useful to summarize the results using the graphical methods developed by Long (1997). For the models that exclude the conservation information variable, Figures $4 a-d$ graph the factor changes (top horizontal axis) and logit coefficients (bottom horizontal axis) for each of the top four programs. The independent variables are on the left-hand side of the graphs; the reported factor changes are a one standard deviation unit change in the relevant independent variable except for succession plan, which is a dummy variable (0 or $1)$. The letters on the graph represent each choice, and lines connecting the choices indicate no statistically significant difference in odds at the $P<0.10$ level. Intuitively, the lines "tie together" choices that are statistically equivalent.

The overall results show some consistent patterns over the top four conservation programs, although the Williamson Act shows some more unique responses. The number of acres managed increases the odds of current participation for all programs except the Williamson Act, with particularly large effects for conservation easements and the CRP. The number of 

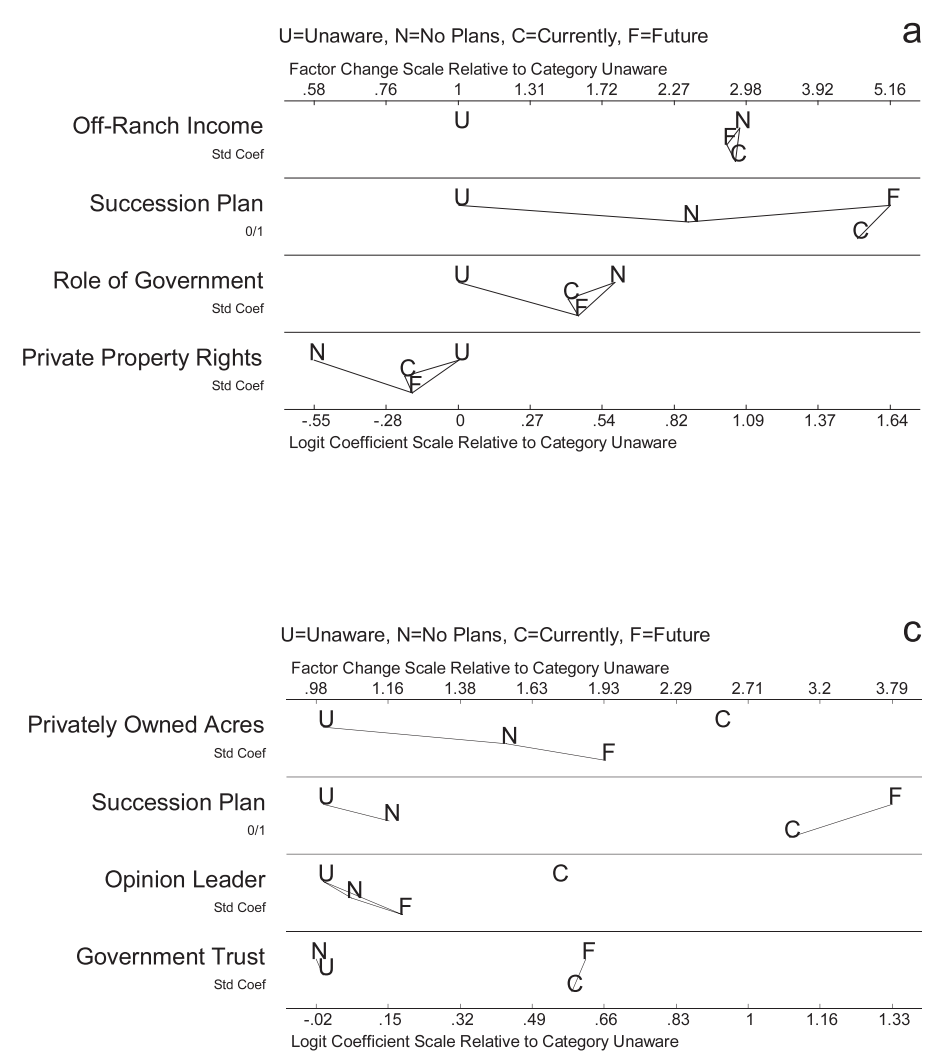

Figure 4. a, Factor changes for Williamson Act. b, Factor changes for the Environmental Quality Incentives Program. c, Factor changes for conservation easements. d, Factor changes for Conservation Reserve Program.

off-ranch income sources increases the odds of currently participating in EQIP, and increases the odds of choosing any outcome except "unaware" for Williamson Act. Education increases the odds of currently participating in EQIP. None of the other hypothesized operator/operation characteristics (Public acres, Income) were statistically significant predictors for any of the top four programs.

The time horizon variables significantly increase participation; ranchers with succession plans are more likely to currently participate in conservation easements, the Williamson Act, and the CRP. Number of generations ranching has a more nuanced effect, with multigenerational ranchers more likely to be aware but not participate in the CRP. For EQIP, multigenerational ranchers are both more likely to be aware but not participate, and to be currently participating. This suggests that while multigenerational ranchers are more likely to be aware of programs, they tend to split between participating and opting out of the program. Possible reasons for this include a particular program not being available in a region, a particular type of ranch not being eligible for a program, or a rancher deciding that the program is not appropriate for the operation.

The opinion leader variable also has a consistent effect on participation choices, increasing the likelihood of currently participating in conservation easements, EQIP, and the CRP. Ranchers who are central in their social networks are more likely to participate in these programs, although again for CRPs and EQIP, there is a small group of opinion leaders who are aware but decline participation. The opinion leader variable has no effect on Williamson Act decisions.

As predicted, government trust has the most consistent effect of all the social values, significantly increasing the odds of current and future participation in all the programs except the Williamson Act. A strong property rights orientation significantly decreases the odds of current participation in the EQIP and CRP, but not at the same magnitude to which government trust increases participation.

Williamson Act participation stands out as potentially different from the other programs. As the most ubiquitous program, $96 \%$ of ranchers are aware of the program and $75 \%$ choose to participate. Hence, there is not much variance to explain, and opinion leadership does not appear to matter. The significance of having a succession plan highlights the importance of maintaining rangeland in Williamson Act contracts over time. Somewhat surprisingly, ranchers with a strong property rights orientation are less likely to have no plans to participate in the Williamson Act program. At the 
Table 2. Negative binomial count model for number of currently participating conservation programs.

\begin{tabular}{lc}
\hline Operator/operation characteristics ${ }^{1}$ & \\
$\bullet$ Private acres & $.01(.004)^{2}$ \\
$\bullet$ Public acres & $.002(.001)^{2}$ \\
•Education & $.04(.03)$ \\
•Income & $.04(.02)$ \\
Off-ranch income sources & $.08(.04)^{2}$ \\
Time horizon & \\
•Succession plan & $.19(.10)^{2}$ \\
•Generations & $.03(.03)$ \\
Social network connections & \\
•Opinion leader & $.14(.05)^{2}$ \\
•Conservation information sources & $.32(.07)^{2}$ \\
Social values & \\
•Role of government & $-.01(.05)$ \\
•Private property rights & $-.03(.04)$ \\
•Government trust & $.13(.04)^{2}$ \\
Constant & $-1.70(.40)$ \\
$N$ & 402 \\
Alpha & $.10(.05)^{2}$ \\
Cragg-Uhler $R^{2}$ & .24 \\
\hline
\end{tabular}

${ }^{1}$ Cell entries are unstandardized slope coefficients (standard errors in parentheses) from a negative binomial regression model, where the dependent variable is a count of the number of conservation programs in which the rancher is currently participating.

${ }^{2}$ Reject null hypothesis of coefficient $=0, P<0.10$.

same time, ranchers who believe the most important role of government is to protect private property rights more significantly are more likely to be aware of the program, and either choose to participate or opt out.

\section{Patterns in Overall Program Participation}

The multinomial logit analysis focuses on the most popular and well-known programs. In order to provide broader insight into overall participation rates in all programs, we use a negative binomial regression model to estimate the influence of all the independent variables listed in Table 1 on the rate of conservation program participation. The dependent variable is the overall participation scale that counts the total number of programs in which the rancher currently participates. The negative binomial model accounts for the fact that there are more zeros (ranchers not participating in any conservation programs) in the distribution than expected under a typical Poisson process (Greene 2000).

The negative binomial results (Table 2) show that larger ranches in terms of both acres of private land and public land have a higher rate of participation. Ranchers with higher numbers of off-ranch income sources also participate in more programs. Having a succession plan consistently increases participation, but multigenerational ranchers do not have a significant higher participation rate. The social network variables are again very important; opinion-leading ranchers who are well-connected to knowledge networks have higher rates of current participation. Of the social values, the most important is government trust, while views regarding private property rights and the role of government do not influence overall participation rates across the suite of possible programs.
Table 3. Correlations between multinomial logit coefficients and proportion of "not aware" respondents.

\begin{tabular}{|c|c|c|c|}
\hline & $\begin{array}{l}\text { Correlation } \\
\text { with } \\
\text { "no plans" } \\
\text { coefficients }{ }^{1}\end{array}$ & $\begin{array}{l}\text { Correlation } \\
\text { with } \\
\text { "currently participating" } \\
\text { coefficients }\end{array}$ & $\begin{array}{l}\text { Correlation } \\
\text { with } \\
\text { "future plans" } \\
\text { coefficients }\end{array}$ \\
\hline Private acres & $-0.75^{2}$ & $-0.81^{2}$ & $-0.71^{2}$ \\
\hline Succession plan & $-0.48^{2}$ & -0.31 & -0.36 \\
\hline Opinion leader & $0.87^{2}$ & $0.47^{2}$ & $0.52^{2}$ \\
\hline Private property rights & $0.60^{2}$ & -0.23 & 0.19 \\
\hline Government trust & 0.07 & 0.00 & 0.41 \\
\hline Conservation information & 0.08 & -0.16 & 0.21 \\
\hline \multicolumn{4}{|c|}{$\begin{array}{l}\text { 1Cell entries are correlation coefficients between the coefficients for multinomial logit models } \\
\text { estimated for every conservation program, and the proportion of respondents who indicated } \\
\text { being "not aware" of the program. Positive correlations mean the multinomial logit coefficient } \\
\text { is increasing as a function of lack of awareness, while negative correlations indicate the } \\
\text { multinomial logit coefficient is decreasing as a function of lack of awareness. } \\
{ }^{2} \text { Reject null hypothesis of coefficient }=0, P<0.10 \text {. }\end{array}$} \\
\hline
\end{tabular}

The negative binomial model masks differences across programs in terms of how different variables might influence participation. As could be seen from the multinomial logit models for the popular programs, there is heterogeneity across programs in the significance and magnitude of different independent variables. One way to appreciate this heterogeneity is to estimate multinomial logit models for every program, and then examine the pattern of coefficients.

We estimated multinomial logit models for every conservation program listed in Figure 2, using private acres, succession plan, conservation information, opinion leader, and government trust as the independent variables. These independent variables were the most consistently significant in the analysis of the most popular programs. Hence, we estimate 18 different multinomial logit models (one for each program), which allows us to examine how the slope coefficients vary across programs. Table 3 shows the correlation between the coefficients for participation (no plans, currently, and future; not aware is the baseline) in each program, and the proportion of respondents who were not aware of the program. Significant positive correlations suggest the importance of the independent variable is increasing as the proportion of "not aware" respondents goes up, and significant negative correlations suggest the importance of the independent variable decreases as the proportion of not aware respondents goes up.

The correlations between lack of awareness and the coefficients for private acres and opinion leader are particularly strong and interesting (Figs. 5a and 5b). As lack of awareness increases, the opinion leader coefficient becomes more positive and significant. Opinion leaders are particularly important for the least popular programs, and will be the first individuals to begin early adoption (Rogers 2003). Conversely, private acres become less important for programs with higher levels of "not aware" respondents. Larger operations begin to take more advantage of conservation programs as their popularity increases in the community. Interestingly, for the least aware programs, the private property rights variable becomes more significant for predicting the choice of "no plans." 

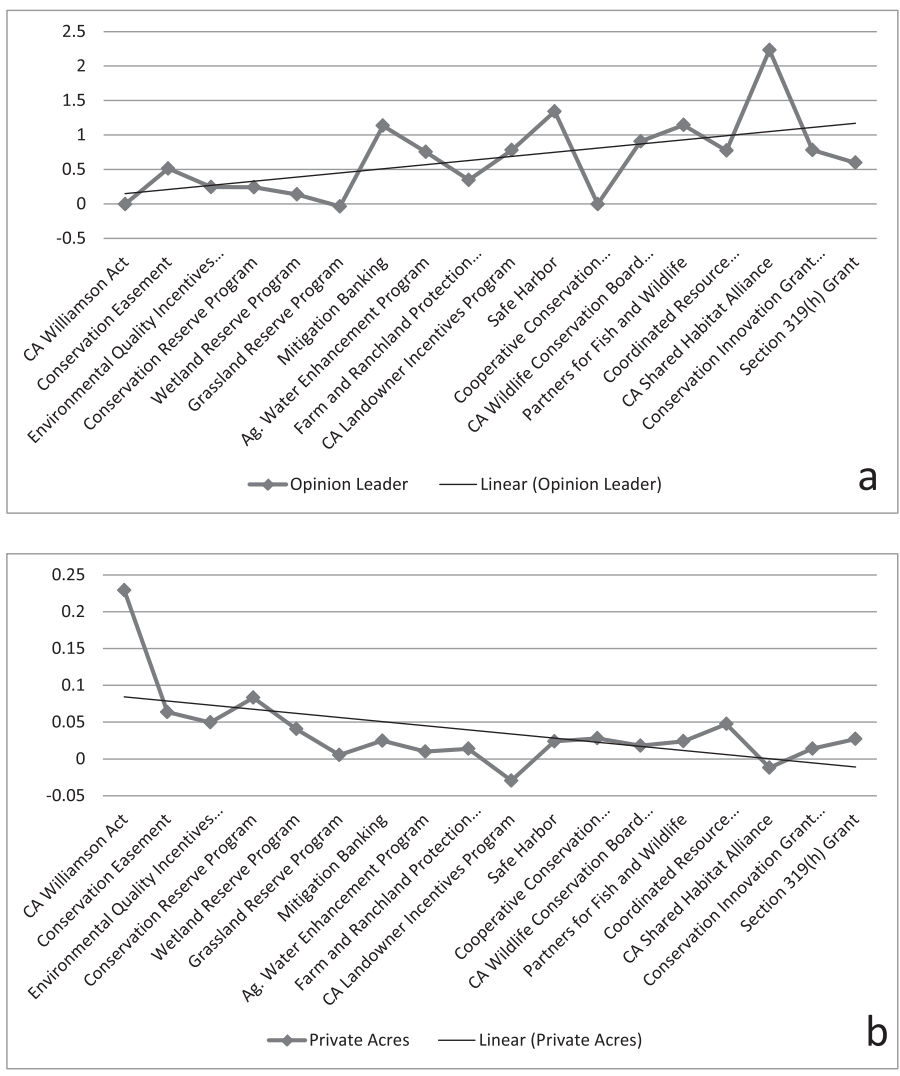

Figure 5. a, Opinion leader coefficients as function of "not aware" respondents. b, Private acres coefficients as function of "not aware" respondents.

\section{The Importance of Conservation Information Sources}

To reiterate, the detailed discussion of the results reported in Figures $4 \mathrm{a}-4 \mathrm{~d}$ are based on the multinomial logit models that exclude conservation information sources as an independent variable. Conservation information sources are actually the most significant variable in the multinomial logit models predicting program participation. However, including conservation information sources as an independent variable makes the strong assumption of no reciprocal influence between program participation and information. In reality, there is likely a positive feedback loop between conservation information and participation, where people continue to invest in learning about conservation programs in ways that reinforce their decisions to participate. Lubell et al. (2011) discuss how knowledge investments are related over time to the perceived costs/benefits of different management strategies and practices.

Regardless of the issue of reciprocal causality, it is still useful to estimate multinomial logit models that include conservation information, and examine how much conservation information affects the predicted probabilities of choosing different levels of participation. Figure 6 graphs the discrete change in predicted probabilities of each choice moving across the entire range of the conservation information variable holding the other variables at their mean levels. The minimum value of 1 on the conservation information variable means the respondent never uses any information sources, while the maximum score of 4 means they believe all of the organizations provided excellent quality information. For example, the predicted
$\mathbb{Q}$ Conservation Reserve Program $\square$ Williamson Act $\square$ EQIP $\square$ Conservation Easement

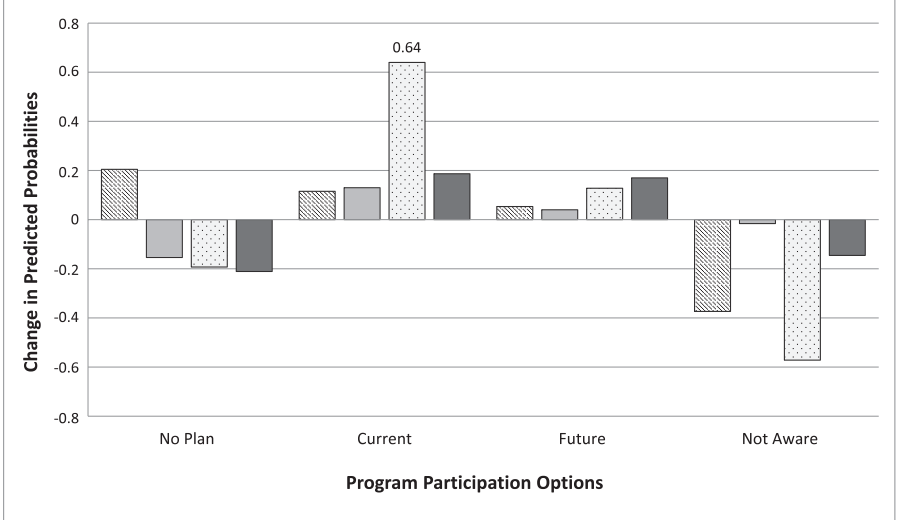

Figure 6. Change in predicted choice probabilities as function of conservation information sources.

probability of currently participating in the EQIP program is 0.06 when conservation information is at the minimum and 0.70 when conservation information is at the maximum; the discrete change labeled on the figure is thus $0.70-0.06=0.64$.

In addition to influencing participation choices, conservation organizations are the second most frequently used sources of information after industry groups like the California Cattleman's Association, the California Farm Bureau, and other ranchers. Seventy-four percent of ranchers report the UC Cooperative Extension as providing good or excellent information, followed by university researchers $(59 \%)$, Natural Resources Conservation Service (56\%), Resource Conservation Districts $(35 \%)$, and conservation groups $(20 \%)$. Not surprisingly, conservation groups receive one of the lowest scores because there is a strong relationship between trust and frequency of contact (Lubell 2007).

\section{DISCUSSION}

The adaptive decision-making framework integrates insights from different theoretical perspectives to identify variables expected to influence participation decisions. Compared to existing frameworks like diffusion of innovation or theory of planned behavior, the adaptive decision-making framework provides a richer conceptualization that recognizes how ranchers respond to changing ecological and social conditions over space, time, and scale. For example, the framework recognizes both the role of networks hypothesized by diffusion theory, and the role of psychological variables from the theory of planned behavior. In addition, it incorporates concepts like time horizons, which is not a central idea in either of the previous theories.

The framework connects to the broader social science literature on decision-making and bounded rationality (Simon 1979; Gigerenzer and Selten 2002), as well as the international literature on pastoralism and rangeland systems that considers how well human communities adapt to environmental change (Gross et al. 2006; McAllister 2012). The contribution of the adaptive decision framework will be enhanced by other forthcoming analyses related to this broader project, including 
the link between goals and management strategies, adoption of different types of grazing systems, and drought preparation.

The survey results find that four programs represent most of the participation (Fig. 3): Williamson Act, EQIP, conservation easements, and the CRP. Participation in the broader menu of programs is limited primarily by a lack of awareness. Thus the adaptive decision-making framework requires simultaneously considering whether or not ranchers know about a conservation program, vs. active nonparticipation, current participation, and future plans to participate. Awareness is the first step in decision-making before the selection of any specific management strategies and practices, and gaining knowledge about options is especially important in complex and uncertain social-ecological systems. For the most popular programs, ranchers who manage more private acres, are connected to local social networks via opinion leadership and contact with local organizations, believe government is helpful for conservation, and plan for long-term sustainability are more likely to participate. In some cases, these variables increase awareness of a program, but then some of the aware ranchers opt in to the program while others opt out. This is consistent with ranchers only choosing to participate in programs that fit into the context of their operational constraints and management goals.

The relevance of these variables appears to vary depending on the level of awareness of a particular program (Table 3). Opinion leadership is more important for less popular programs with a limited level of awareness, while the size of the ranching operation is more important for predicting participation in popular programs. Taken together, this suggests that participation in conservation programs begins with opinion leaders, who are among the first to adopt and promote them through their social networks. Over time, as participation grows, programs begin to attract some of the larger operations. To the extent this pattern holds among the smaller ranches that are underrepresented in our study, it is likely that opinion leaders and early adopters can be found even among smaller operations. This type of heterogeneity is not typically considered in analyses of conservation program participation.

Conservation information sources have an especially strong effect on EQIP and conservation easement participation, where more information increases the probability of current participation while simultaneously decreasing the probability of being completely unaware or having no plans to participate (Fig. 6). The effect is less pronounced for the CRP, where more information decreases the probability of being unaware, but with a smaller increase in the probability of current or future participation. This is consistent with the idea that for less popular programs, awareness is the first step in decisionmaking.

\section{IMPLICATIONS}

Rangeland stakeholders should develop policy and outreach strategies that enhance the usefulness of conservation programs for adapting to social-ecological programs. To increase participation, outreach strategies should target opinion leaders who are well-connected to local social networks, and capitalize on the desire of many ranchers to maintain the family and historical legacies of their operations. Those opinion leaders should be encouraged to reach out to smaller landowners and new ranchers, who can form the basis for conservation management into the future. Property rights concerns are potentially becoming less relevant, but it is crucial to develop trust-based relationships between ranchers and organizations that administer conservation programs.

At the institutional level, collaborative partnerships like the California Rangeland Conservation Coalition can foster cooperation and innovation. Ranchers and other agricultural communities are using partnerships to address new socialecological problems, for example through the formation of prescribed burning associations to deal with invasive species and brush encroachment on many Western rangelands (Kreuter et al. 2008; Toledo et al. 2012) and local programs for sustainability (Lubell et al. 2011; Shaw et al. 2011). Partnerships encourage participation by providing a trusted source of information about conservation programs, and helping navigate bureaucratic processes. Partnerships can serve as boundary-spanning organizations (Guston 2001; Carr and Wilkinson 2005), which seek to build social relationships and trust among the increasingly diverse set of stakeholders with interests in both the economic and ecosystem services of rangeland systems. These same partnerships can serve the role of "translational science," helping integrate scientific research on ecosystem services with traditional ranching expertise developed in the context of generations of ranchers (Briske 2012). Designing partnerships that capitalize on the decision strategies of ranchers can help enhance the overall sustainability, resilience, and adaptive capacity of rangeland social-ecological systems.

\section{LITERATURE CITED}

Ahnström, J., J. Höckert, H. L. Berge̊̊, C. A. Francis, P. Skelton, and L. Hallgren. 2009. Farmers and nature conservation: what is known about attitudes, context factors and actions affecting conservation? Renewable Agriculture and Food Systems 24:38-47.

AJzen, I., AND M. FISHBEIN. 1980. Understanding attitudes and predicting social behavior. Englewood Cliffs, NJ, USA: Prentice-Hall. 296 p.

BRISKE, D. D. [ED.]. 2011. Conservation benefits of rangeland practices: assessment, recommendations, and knowledge gaps. Lawrence, KS, USA: Allen Press. 429 p.

BRISKE, D. D. 2012. Translational science partnerships: key to environmental stewardship. BioScience 62(5):449-450.

Brunson, M. W. 2012. The elusive promise of social-ecological approaches to rangeland management. Rangeland Ecology \& Management 65:632-637.

Brunson, M. W., And L. Huntsinger. 2008. Ranching as a conservation strategy: can old ranchers save the New West? Rangeland Ecology \& Management 61:137147.

Buttel, F. H., And H. Newby. 1980. The rural sociology of the advanced societies: critical perspectives. Montclair, NJ, USA: Allanheld, Osmun. 529 p.

Calffornia Rangeland Trust. 2011. Annual report 2010-2011. Available at: http://www. rangelandtrust.org/files/2010_Annual_Report_Final_Final.pdf. Accessed 15 May 2013.

CarR, A., And R. Wilkinson. 2005. Beyond participation: boundary organizations as a new space for farmers and scientists to interact. Society \& Natural Resources 18:255-265.

Christensen, J., J. Rempel, And J. BurR. 2011. Land trusts thrive despite, and because of, the Great Recession. High Country News. 12 December. Available at: http:// www.hcn.org/issues/43.21/land-trusts-thrive-despite-and-because-of-the-greatrecession. Accessed 17 October 2013. 
ClaAssen, R. 2011. USDA conservation spending on working agricultural lands bucks long-term trend. Amber Waves 9:60.

Coppock, D. L., AND A. H. BIRKEnfeLd. 1999. Use of livestock and range management practices in Utah. Journal of Range Management 52:7.

CoRtinA, J. M. 1993. What is coefficient alpha? An examination of theory and applications. Journal of Applied Psychology 78:98-104.

Didier, E. A., ANd M. W. Brunson. 2004. Adoption of range management innovations by Utah ranchers. Journal of Range Management 57:330.

Dıııman, D. A. 2007. Mail and internet surveys: the tailored design method. 2nd ed. Hoboken, NJ, USA: John Wiley \& Sons. $544 \mathrm{p}$.

Ferranto, S., L. Huntsinger, C. Getz, G. Nakamura, W. Stewart, S. Drill, Y. Valachovic, M. Delasaux, and M. Kelly. 2011. Forest and rangeland owners value land for natural amenities and as financial investment. California Agriculture 65:184-191.

Folke, C., T. Hahn, P. Olsson, And J. Norberg. 2005. Adaptive governance of socialecological systems. Annual Review of Environment and Resources 30:441-473.

Fox, W. E., D. W. McCollum, J. E. Mitchell, L. E. Swanson, G. R. Evans, H. T. Heintz, JR., J. A. Tanaka, U. P. Kreuter, R. P. Breckenridge, and P. H. Geissler. 2009. An integrated social, economic, and ecologic conceptual (ISEEC) framework for considering rangeland sustainability. Society \& Natural Resources 22:593-606.

Fuglie, K. O., And C. A. KascaK. 2001. Adoption and diffusion of natural-resourceconserving agricultural technology. Review of Agricultural Economics 23:386403.

Gigerenzer, G., AND R. Selten [eds.]. 2002. Bounded rationality: the adaptive toolbox. Cambridge, MA, USA: MIT Press. 393 p.

GILLsON, L., AND T. Hoffman. 2007. Rangeland ecology in a changing world. Science 315:53-54.

Greene, W. H. 2000. Econometric analysis. 4th ed. Upper Saddle River, NJ, USA: Prentice Hall. 1075 p.

Gross, J. E., R. R. J. McAllister, N. Abel, D. M. S. Smith, and Y. Maru. 2006. Australian rangelands as complex adaptive systems: a conceptual model and preliminary results. Environmental Modelling \& Software 21:1264-1272.

Guston, D. H. 2001. Boundary organizations in environmental policy and science: an introduction. Science, Technology \& Human Values 26:399-408.

Havstad, K. M., D. P. C. Peters, R. Skaggs, J. Brown, B. Bestelmeyer, E. Fredrickson, J. HerRick, AND J. WriGht. 2007. Ecological services to and from rangelands of the United States. Ecological Economics 64:261-268.

Huntsinger, L., And P. Hopkinson. 1996. Viewpoint: Sustaining rangeland landscapes: a social and ecological process. Journal of Range Management 49:167-173.

Huntsinger, L., M. Johnson, M. StafFord, and J. Fried. 2010. Hardwood rangeland landowners in California from 1985 to 2004: production, ecosystem services, and permanence. Rangeland Ecology \& Management 63:324-334.

Iyengar, R., C. V. den Bulte, and T. W. Valente. 2011. Opinion leadership and social contagion in new product diffusion. Marketing Science 30:195-212.

JaCkson-Smith, D., U. Kreuter, and R. S. Krannich. 2005. Understanding the multidimensionality of property rights orientations: evidence from Utah and Texas ranchers. Society \& Natural Resources 18:587-610.

KaBII, T., AND P. HoRwITz. 2006. A review of landholder motivations and determinants for participation in conservation covenanting programmes. Environmental Conservation 33:11-20.

Knapp, C. N., and M. E. Fernandez-Gimenez. 2009. Understanding change: integrating rancher knowledge into state-and-transition models. Rangeland Ecology \& Management 62:510-521.

Kollmuss, A., And J. Agyeman. 2002. Mind the gap: why do people act environmentally and what are the barriers to pro-environmental behaviour? Environmental Education Research 8:239-260.

Kreuter, U. P., M. V. Nair, D. Jackson-Smith, J. R. Conner, and J. E. Johnston. 2006. Property rights orientations and rangeland management objectives: Texas, Utah, and Colorado. Rangeland Ecology \& Management 59:632-639.

Kreuter, U. P, M. Tays, and J. R. Conner. 2004. Landowner willingness to participate in a Texas brush reduction program. Rangeland Ecology \& Management 57:230237.

Kreuter, U. P., J. B. Woodard, C. A. Taylor, and W. R. Teague. 2008. Perceptions of Texas landowners regarding fire and its use. Rangeland Ecology \& Management 61:456-464
LAl, P., AND U. P. Kreuter. 2012. Examining the effects of environmental change and place attachment on land management choices in the Hill Country of Texas, USA. Landscape and Urban Planning 104:320-328.

LoNG, J. S. 1997. Regression models for categorical and limited dependent variables. 1st ed. Thousand Oaks, CA, USA: SAGE Publications. 328 p.

LUBELL, M. 2007. Familiarity breeds trust: collective action in a policy domain. Journal of Politics 69:237-250.

LubelL, M., AND A. Fulton. 2008. Local policy networks and agricultural watershed management. Journal of Public Administration Research and Theory 18:673696.

Lubell, M., A. Hillis, And M. Hoffman. 2011. Innovation, cooperation, and the perceived benefits and costs of sustainable agriculture practices. Ecology and Society 16:23.

McAluIster, R. R. J. 2012. Livestock mobility in arid and semiarid Australia: escaping variability in space. The Rangeland Journal 34:139-147.

McAllister, R. R. J., N. Abel, C. J. Stokes, and I. J. Gordon. 2006. Australian pastoralists in time and space: the evolution of a complex adaptive system. Ecology and Society 11:1-16.

McAluster, R. R. J., D. M. S. Smith, C. J. Stokes, and F. J. Walsh. 2009. Patterns of accessing variable resources across time and space: desert plants, animals and people. Journal of Arid Environments 73:338-346.

Merenlender, A. M., L. Huntsinger, G. Guthey, and S. K. Fairfax. 2004. Land trusts and conservation easements: who is conserving what for whom? Conservation Biology 18:65-76.

Mishra, A. K., AND H. S. EL-Osta. 2007. Factors affecting succession decisions in family farm businesses: evidence from a national survey. Journal of the American Society of Farm Managers and Rural Appraisers 7:1-10.

Molitor, D., O. Hinz, and S. Wegmann. 2011. The interplay between psychometric and sociometric data and the willingness to adopt innovations. Zeitschrift für Betriebswirtschaft 81:29-59.

Napier, T. L., M. TuCKer, and S. McCARTer. 2000. Adoption of conservation production systems in three Midwest watersheds. Journal of Soil and Water Conservation $55: 123-134$.

National Agricultural Statistical Service. 2007. Census of agriculture: state data: California. Available at: http://www.agcensus.usda.gov/Publications/2007/ Full_Report/Volume_1,_Chapter_1_State_Level/California/st06_1_064_064.pdf. Accessed 22 May $201 \overline{3}$.

Pavelis, G., D. Helms, and S. Stalcup. 2011. Soil and water conservation expenditures by USDA agencies, 1935-2010. Washington, DC, USA: USDA/NRCS Historical Insights. $24 \mathrm{p}$.

Payne, J. W., J. R. Bettman, and E. J. Johnson. 1990. The adaptive decision maker: effort and accuracy in choice. In: Insights in decision making: a tribute to Hillel $\mathrm{J}$. Einhorn, ed. Robin M. Hogarth. Chicago, IL, USA: University of Chicago Press. p. 129-153.

Peffley, M. A., And HuRwitz, J. 1985. A hierarchical model of attitude constraint. American Journal of Political Science 29:871-890.

Peterson, R., and D. L. Coppock. 2001. Economics and demographics constrain investment in Utah private grazing lands. Journal of Range Management 54:106114.

Prokopy, L. S., K. Floress, D. Klotthor-Weinkauf, and A. Baumgart-Getz. 2008. Determinants of agricultural best management practice adoption: Evidence from the literature. Journal of Soil and Water Conservation 63(5):300.

Quaas, M. F., S. Baumgärtner, C. Becker, K. Frank, and B. MÜller. 2007. Uncertainty and sustainability in the management of rangelands. Ecological Economics 62:251-266.

Rissman, A. R., And N. F. Sayre. 2012. Conservation outcomes and social relations: a comparative study of private ranchland conservation easements. Society \& Natural Resources 25:523-538.

Rogers, E. 2003. Diffusion of innovations. 5th ed. New York, NY, USA: Free Press. $576 \mathrm{p}$.

Shaw, L., M. Lubell, and C. Ohmart. 2011. The evolution of local partnerships for sustainable agriculture. Society and Natural Resources 24:1078-1095.

SImon, H. A. 1979. Models of thought. Volume I. New Haven, CT, USA: Yale University Press. 524 p. 
Sorice, M. G., J. R. Conner, U. P. Kreuter, and R. N. Wilkins. 2012. Centrality of the ranching lifestyle and attitudes toward a voluntary incentive program to protect endangered species. Rangeland Ecology \& Management 65:144-152.

Sorice, M. G., W. Haider, J. R. Conner, and R. B. Ditton. 2011. Incentive structure of and private landowner participation in an endangered species conservation program. Conservation Biology 25:587-596.

Stafford Smith, D. M., and R. R. J. McAlulster. 2008. Managing dryland natural resources for spatial and temporal variability: an approach from first principles. The Rangeland Journal 30:15-27.
SULAK, A., AND L. Huntsinger. 2002. Sierra Nevada grazing in transition: the role of Forest Service grazing in the foothill ranches of California. Tahoe, CA, USA: Sierra Nevada Alliance. 35 p.

Thurow, T. L., A. P. Thurow, and M. D. Garriga. 2000. Policy prospects for brush control to increase off-site water yield. Journal of Range Management 53:23-31.

Toledo, D., U. P. Kreuter, M. G. Sorice, and C. A. Taylor, JR. 2012. To burn or not to burn: ecological restoration, liability concerns and the role of prescribed burning associations. Rangelands 34:18-23.

Valente, T. W., And P. Pumpuang. 2007. Identifying opinion leaders to promote behavior change. Health Education \& Behavior 34:881-896. 